\title{
Alleviation of phytotoxic effect of heavy metals on wheat by multiple heavy metal tolerant Pseudomonas aeruginosa HMT 7
}

\section{Monica Sen}

Mohanlal Sukhadia University Faculty of Science

HARSHADA JOSHI ( $\nabla$ hjbiotech@gmail.com)

Mohan Lal Sukhadia University https://orcid.org/0000-0002-2348-3098

\section{Research Article}

Keywords: Multiple heavy metal tolerance, Pseudomonas aeruginosa HMT 7, heavy metal toxicity, plant growth parameters, Triticum aestivum L.

Posted Date: February 2nd, 2022

DOI: https://doi.org/10.21203/rs.3.rs-1190413/v1

License: @ (i) This work is licensed under a Creative Commons Attribution 4.0 International License. Read Full License 


\begin{abstract}
Heavy metal pollution in soils and water bodies is becoming a serious threat to environment and is a matter of wide concern. This study was carried out on soil bacterial strain isolated from heavy metal contaminated soil collected from Zawar, Udaipur (India) with the aim of exploring the impacts of land use on heavy metal contamination of soil and sediment. A total of 23 zinc tolerant isolates were recovered on nutrient agar supplemented with 1 mM concentration of zinc sulphate heptahydrate. Out of which isolate HMT 7 which showed highest MIC of $31 \mathrm{mg} / \mathrm{ml}$ was further characterized by morphological, cultural, biochemical and molecular characterization and was identified as Pseudomonas aeruginosa HMT 7. The isolate showed multiple heavy metal tolerance and grew in presence of zinc sulphate heptahydrate $(30 \mathrm{mg} / \mathrm{ml})$, cadmium chloride $(100 \mu \mathrm{g} / \mathrm{ml})$ and lead nitrate $(100 \mu \mathrm{g} / \mathrm{ml})$. The heavy metal accumulation by the isolate was also evidenced by transmission electron microscopy. A pot experiment under heavy metal stress conditions was performed using Triticum aestivum L. as a test crop. Heavy metal toxicity reduced various plant growth parameters; however, inoculation of Pseudomonas aeruginosa HMT 7 alleviated the heavy metal toxicity and enhanced the plant growth parameters.
\end{abstract}

\title{
Introduction
}

Soil is natural a habitat of large number of organisms and also plays an important role in material recycling and energy exchange in terrestrial ecosystems. Rapid industrialization has led to soil pollution which poses serious environmental threat causing alarming situation [1]. Increased heavy metal concentrations are particularly harmful because heavy metals are toxic, persistent, and non-degradable [2]. The lead-zinc ore processing plant of Zawar group of mines (Udaipur district) is processing large amount ores. The commonly used ores from Mochia and Balaria mines of Zawar are composed of different amounts of lead, zinc and iron ranging from 1 to $7 \%$. Significant quantities of cadmium and silver are also present in them. After processing of different ores, large amount of waste ( $90 \%$ ) is produced which is dumped in the tailing dams. The waste contains $0.05-0.1 \%$ lead, $0.16-0.3 \%$ zinc, $3-5 \%$ iron, $3-4 \%$ sulphur, $13-14 \%$ calcium, $8-9 \%$ magnesium and $31-33 \%$ acid insolubles. The finer particles from the tailing dams are carried away by the wind during the dry season and the atmosphere becomes polluted with dust. The waste present in the tailing dams is continuously increasing the heavy metal ( $\mathrm{Zn}, \mathrm{Pb}, \mathrm{Cd}, \mathrm{Fe}) \mathrm{content}$ of the soil in nearby area resulting in barren lands that is expanding nearby.

Dumping of mining wastes mounts pressure on the ecosystem and consequently causes health hazards to plants animals and humans $[3,4,5]$. The accumulation of heavy metals in top soil acts as a reservoir to spread them into water bodies, atmosphere as well in food chain of organisms. The soil of such areas becomes unfavorable for growth and development of plants and rhizospheric microorganisms [6, 7]. Excessive amounts of heavy metals like zinc, cadmium and lead negatively affect plant growth, reduce photosynthetic rate and enhances the production of reactive oxygen species. Besides all these negative aspects the exposure of heavy metals induces the development of resistance mechanisms among the microbial population [8]. Use of these microorganisms for reclamation of affected land can be beneficial to reverse the properties of soil which in turn will be important to reduce the toxic impact of heavy metals to ecosystem and to human health [9]. To explore the potential of heavy metal tolerant bacteria for possible use in restoration of contaminated sites the present investigation was designed to study the isolation and identification of multiple heavy metal tolerant bacteria from polluted soil of tailing dam of Zawar (Udaipur) India.

\section{Methods And Materials Physicochemical analysis of soil samples}

Soil samples were collected from rhizosphere of Tridex plant growing in tailing dam in Zawar, Udaipur (India). Zawar ( $24^{\circ} 21^{\prime} \mathrm{N}$; $\left.73^{\circ} 41^{\prime} \mathrm{E}\right)$, is an ancient zinc smelting site, situated about $40 \mathrm{~km}$ southeast of Udaipur. Collection of these samples was done in sterilized zipper polythenes. The soil samples were air dried, sieved, and kept for the analysis. The electrical conductivity, $\mathrm{pH}$ and organic carbon were analyzed [10] and quantitative analysis of heavy metals in soil samples was carried out using atomic absorption spectrophotometer.

\section{Determination of minimum inhibitory concentration (MIC) of zinc}

The zinc tolerant bacteria were isolated by serial dilution and pour plate method using nutrient agar amended with $1 \mathrm{mg} / \mathrm{ml}$ concentration of zinc sulphate heptahydrate. The plates were incubated at $37^{\circ} \mathrm{C}$ for $24 \mathrm{~h}$. The MIC of zinc, at which no colony growth occurred, was determined by the agar dilution method [11]. All the zinc tolerant bacterial isolates were grown on nutrient agar plates with gradually increasing the concentration of the zinc ions. The lowest concentration of zinc ions that inhibited the growth of zinc tolerant bacteria was taken as the MIC of the metal.

\section{Characterization of the isolates}

Morphological and biochemical identification tests of the isolate was carried out by using the standard protocol outlined in Bergey's Manual of Systemic Bacteriology. The bacterial culture was submitted to Microbial Type Culture Collection, Institute of Microbial Technology, Chandigarh for FAME analysis. The fatty acid profiles of the isolate were fed to MIDI microbial identification system for calculation of similarity (SIM) index. Molecular identification of the isolate was done using 16S rDNA amplification and sequencing. The universal primers for 16S rDNA viz. 27f (5'- AGAGTTTGATCMTGGCTCAG-3') and 1492r (5'TACGGYTACCTTGTTACGACTT- 3') [12] based on 16S rRNA gene sequence of bacteria were used to amplify the genomic DNA. The amplified products were submitted to Bangalore Genei Pvt. Ltd., Bangalore (India) for sequencing. The partial sequences of 16S rRNA were compared with available standard sequences of bacterial lineages in the NCBI Genbank using Basic local alignment search tool (BLASTn) to identify the nearest taxa.

\section{Detection of antibiotic resistance}

The antibiotic resistance pattern of isolates was studied on nutrient agar medium by Kirby-Bauer disc diffusion method [13]. The different antibiotic discs (Himedia) were used and the nutrient agar plates were incubated at $37^{\circ} \mathrm{C}$ for $24 \mathrm{~h}$. After the incubation, zone of growth of inhibition around each disc was 
measured and used to classify the organisms as sensitive or resistant to an antibiotic according to the Clinical and Laboratory Standards Institute (CLSI) standards.

\section{Determination of multiple heavy metal tolerance}

To determine the multiple heavy metal tolerance isolate was grown with appropriate concentrations of three heavy metal compounds namely zinc sulphate heptahydrate, cadmium chloride and lead nitrate. The nutrient broth was inoculated with test culture and incubated at $37^{\circ} \mathrm{C}$ for $24 \mathrm{~h}$. The growth was measured spectrophotometrically.

\section{Transmission electron microscopy analysis for accumulation of heavy metals}

The heavy metal tolerant isolates were submitted to Sophisticated Instrumentation Centre for Applied Research and Testing (SICART) Vallabh Vidhyanagar, Anand (Gujarat) to detect the accumulation of heavy metals using transmission electron microscope. The isolates were inoculated in nutrient broth supplemented with appropriate concentration of heavy metal compounds. Incubation was done at $37^{\circ} \mathrm{C}$ for $24 \mathrm{~h}$. The nutrient broth containing growth was then centrifuged at 3000rpm for 15 minutes. The pellet of bacterial cells was resuspended in MQ water in microfuge tube and then was submitted for TEM analysis.

\section{Plasmid isolation}

The heavy metal tolerant isolate was subjected to plasmid isolation by minipreparations using alkaline lysis method [14]. For plasmid isolation, the bacterial culture was treated with a series of lysis solution with a fixed interval of time. After centrifugation, plasmid is precipitated using sodium acetate and ethanol. The plasmid DNA samples were checked by electrophoresis on $0.8 \%$ horizontal agarose gel.

\section{Studies to determine the effect of multiple heavy metal tolerant isolate on growth of wheat under heavy metal stress}

The pot experiment for selected multiple heavy metal tolerant bacterial isolate was conducted in pots filled with sterile soil ( $1.5 \mathrm{Kg} / \mathrm{pot})$. The soil was sieved ( 2 $\mathrm{mm}$ ) and sterilized by autoclaving. The experiment was designed in complete randomized design (CRD) with three treatments. The details of the treatments are: T0 (control, uncontaminated soil), TZ1 (1,000 mg Zn/kg, 1 mg Cd/Kg and 1mg Pb/Kg amended soil), TZ2 (1,000 mg Zn/kg, 1 mg Cd/Kg and 1mg Pb/Kg amended soil +bacterial isolate. The pots were left for 2 weeks for metal stabilization. The bacterial culture was grown for $48 \mathrm{~h}$, cells harvested by centrifugation (6000 rpm, $10 \mathrm{~min}$ ), washed twice with sterile distilled water, and resuspended in biological saline $(0.85 \% \mathrm{NaCl})$. Bacterial suspensions were adjusted to an absorbance of 0.5 at $620 \mathrm{~nm}$. Seeds of Triticum aestivum var. RAJ 4238 were surface-sterilized by immersing them in $0.1 \%$ sodium hypochlorite solution for $10 \mathrm{~min}$ and then washed three times with double distilled water. Surface sterilized seeds were then soaked in bacterial suspension approximately $30 \mathrm{~min}$ prior to planting, while for T0 and TZ1 treatment seeds were soaked in sterile biological saline. The experiment was conducted in triplicates and 5 seeds were sown in each pot. Seedling emergence was recorded daily. The potted plants were cultivated with open-field conditions. They received a full sun exposure, regular watering and no fertilizers. After 45 days, the plants were carefully removed from the pots and the root surface was thoroughly cleaned with distilled water and blot dried. Different growth parameters like average shoot and root length, fresh and dry weight were analysed. Stress tolerance indices for different growth parameters were calculated [15].

\section{Statistical analysis}

All the experiments were carried out in triplicate and data is presented as mean \pm standard deviation. The experimental data were analysed statistically by estimating the standard deviation using MS-Excel 2003. Statistical analysis was carried out using a statistical package GraphPad Prism. Comparison between mean values in different treatments for studying the effect of heavy metal tolerant bacterial isolate on growth of Triticum aestivum $\mathrm{L}$. was carried through the student test (t-test) with confidence levels of $5 \%$ or $P \leq 0.05$ being considered significant.

\section{Results}

\section{Physicochemical analysis of soil samples}

In the present study, the soil samples were collected from rhizosphere of Tridax sp. plant growing in tailing dam in Zawar, Udaipur (India). The soil of the area was found to be slightly alkaline and high range of electrical conductivity and organic carbon. The amount of zinc, cadmium, lead and iron was found quite higher than the permissible limit of heavy metals in soil. The higher heavy metal contents are attributed to the zinc smelting and mining activities in this area. The data obtained is presented in Table 1.

Table 1

Heavy metal content of rhizospheric soil sample collected from Zawar, Udaipur, India

\begin{tabular}{|c|c|c|c|c|c|c|c|c|}
\hline \multirow[t]{2}{*}{ Sample collection site } & \multirow[t]{2}{*}{ Satellite location } & \multirow[t]{2}{*}{$\mathrm{EC}(\mathrm{dS} / \mathrm{m})$} & \multirow[t]{2}{*}{$\mathrm{pH}$} & \multirow{2}{*}{$\begin{array}{l}O C \\
(g / K g)\end{array}$} & \multicolumn{4}{|c|}{ Heavy Metal Content (mg/Kg) } \\
\hline & & & & & Zinc & Cadmium & Lead & Iron \\
\hline Tailing dam, Zawar & $\left(24^{\circ} 21^{\prime} \mathrm{N} ; 73^{\circ} 41^{\prime} \mathrm{E}\right)$ & 0.59 & 7.21 & 0.71 & 1500 & 15 & 1780 & 3560 \\
\hline
\end{tabular}

Minimum inhibitory concentration (MIC) of zinc tolerant bacteria 
A total of 23 zinc tolerant bacterial isolates (isolate HMT 1 to isolate HMT 23) were recovered during the isolation procedure. All the strains were subjected for determination of MIC against zinc and four isolates namely HMT 7, HMT 11, HMT16 and HMT19 showed high MIC value of 31, 21, 26 and 18 mg/ml respectively. Isolate HMT 7 showed highest MIC value and therefore selected for further studies.

\section{Characterization of zinc tolerant isolate}

The colonies of zinc tolerant isolate HMT7 on nutrient agar appeared medium sized, red-brown, irregular, undulate and flat. Isolate was identified as gramnegative rod. Isolate HMT 7 showed positive reaction for an array of biochemical reactions viz. catalase test, oxidase test, oxidation fermentation (o/f) test, nitrate reduction, citrate utilization, gelatin hydrolysis, arginine hydrolysis test and negative reaction for starch hydrolysis. It showed growth on MacConkey and cetrimide agar and produced green pigment on King's A medium and fluorescence on King's B medium (Table 2). Isolate HMT 7 gave negative reaction for the fermentation of ten common sugars namely dextrose, sucrose, galactose, maltose, mannose, inositol, fructose, cellobiose, lactose, and rhamnose which suggested that the isolate was non-fermentative. FAME analysis for isolate HMT 7 (Fig. 1) revealed that SIM index reached to 0.752 and the possible strain suggested by the MIDI software was Pseudomonas aeruginosa which was further confirmed by $16 \mathrm{~S}$ rRNA sequencing. The $16 \mathrm{~S}$ rRNA sequence of the isolated DNA was amplified using universal primers, $27 \mathrm{f}$ and $1492 \mathrm{r}$ in PCR and an amplified product of 1.5Kb was obtained (Fig. 2). Isolate HMT 7 showed $99 \%$ sequence similarity to Pseudomonas aeruginosa strain UKMP14 therefore it was identified and named as Pseudomonas aeruginosa HMT 7.

Table 2

Biochemical characterization of heavy metal tolerant bacterial isolate HMT7

\begin{tabular}{|c|c|c|c|c|c|c|c|c|c|c|c|c|}
\hline $\begin{array}{l}\text { Name } \\
\text { of the } \\
\text { isolate }\end{array}$ & $\begin{array}{l}\text { Catalase } \\
\text { test }\end{array}$ & $\begin{array}{l}\text { Oxidase } \\
\text { test }\end{array}$ & $\begin{array}{l}\text { O/F } \\
\text { media }\end{array}$ & $\begin{array}{l}\text { Nitrate } \\
\text { Reduction } \\
\text { test }\end{array}$ & $\begin{array}{l}\text { Citrate } \\
\text { utilization } \\
\text { test }\end{array}$ & $\begin{array}{l}\text { Arginine } \\
\text { hydrolysis }\end{array}$ & $\begin{array}{l}\text { Gelatin } \\
\text { liquification }\end{array}$ & $\begin{array}{l}\text { Starch } \\
\text { hydrolysis }\end{array}$ & $\begin{array}{l}\text { Growth on } \\
\text { McConkey } \\
\text { agar }\end{array}$ & $\begin{array}{l}\text { Growth } \\
\text { on } \\
\text { Cetramide } \\
\text { agar }\end{array}$ & $\begin{array}{l}\text { Growth } \\
\text { on } \\
\text { King's } \\
\text { A } \\
\text { media }\end{array}$ & $\begin{array}{l}\text { Grow } \\
\text { on } \\
\text { King: } \\
\text { B } \\
\text { medi: }\end{array}$ \\
\hline $\begin{array}{l}\text { Isolate } \\
\text { HMT } \\
7\end{array}$ & + & + & + & + & + & + & + & - & + & + & + & + \\
\hline
\end{tabular}

$+=$ positive, - = negative

\section{Antibiotic resistance pattern of $P$. aeruginosa HMT 7}

P. aeruginosa HMT 7 showed resistance to six different antibiotics viz. ampicillin (10 mcg), cefixime (5mcg), erythromycin (15mcg), penicillin (10mcg), trimethoprim $(5 \mathrm{mcg})$ and vancomycin $(30 \mathrm{mcg})$ and sensitive to remaining antibiotics viz. amikacin (30mcg), ciprofloxacin (5mcg), chloramphenicol (30 mcg), gentamicin (30 mcg), kanamycin (30 mcg), polymyxin $(300 \mathrm{mcg})$, rifampicin $(30 \mathrm{mcg})$, streptomycin $(25 \mathrm{mcg})$ and tetracycline (30mcg).

\section{Multiple heavy metal tolerance of $P$. aeruginosa HMT 7}

The zinc tolerant $P$. aeruginosa HMT 7 was inoculated on nutrient agar supplemented with $30 \mathrm{mg} / \mathrm{ml}$ of zinc sulphate heptahydrate, $100 \mu \mathrm{g} / \mathrm{ml}$ of cadmium chloride and $100 \mu \mathrm{g} / \mathrm{ml}$ of lead nitrate. The isolate inoculated in nutrient broth without any heavy metal was kept as control. It was observed that $P$. aeruginosa HMT 7 maintained fairly high growth $(96 \%)$ in presence of multiple heavy metals thereby confirming multiple heavy metal tolerance.

\section{TEM analysis for accumulation of heavy metals}

To localize the intracellular site for accumulation of heavy metals the cells of $P$. aeruginosa HMT 7 were observed under TEM. The transmission electron micrograph (Fig. 3) revealed electron dense grains in the cytosol and towards the cell envelope.

\section{Plasmid profile}

P. aeruginosa HMT 7 was subjected to plasmid isolation by minipreparations using alkaline lysis. It was found to harbor single plasmid of approximately 23 $\mathrm{Kb}$ size (Fig. 4).

\section{Promotion of plant growth by $P$. aeruginosa HMT 7 on wheat under stress}

The alleviation of phytotoxicity of heavy metals by multiple metal tolerant $P$. aeruginosa HMT 7 on the growth of wheat (Triticum aestivum var. RAJ 4238 ) was studied. The study was conducted based on three treatments as T0 (control, uncontaminated soil), TZ1 (1,000 mg Zn/kg, $1 \mathrm{mg} \mathrm{Cd} / \mathrm{Kg}$ and 1mg Pb/Kg amended soil), TZ2 (1,000 mg Zn/kg, $1 \mathrm{mg} \mathrm{Cd} / \mathrm{Kg}$ and $1 \mathrm{mg} \mathrm{Pb} / \mathrm{Kg}$ amended soil inoculated with multiple metal tolerant $P$. aeruginosa HMT 7). The pot experiment data were recorded under heavy metals stress condition after 45 days of germination and summarized in Table 3. In uninoculated control TZ1 (1,000 mg Zn/kg, $1 \mathrm{mg} \mathrm{Cd} / \mathrm{Kg}$ and $1 \mathrm{mg} \mathrm{Pb} / \mathrm{Kg}$ amended soil) the overall plant growth was significantly decreased due to the heavy metals stress compared to control plantlets T0 (without any heavy metals stress). The stress tolerance indices for different growth parameters shoot length, root length, shoot and root dry and fresh weight observed were $0.57,0.60,0.45,0.35,0.65$ and 0.60 respectively. Whereas, higher plant growth was observed in wheat plantlets treated with multiple metal tolerant $P$. aeruginosa HMT 7 (TZ2) compared to uninoculated control). The stress tolerance indices for different growth parameters shoot 
length, root length, shoot and root dry and fresh weight observed were 2.28, 1,89, 3.02, 3.91, 1.92 and 2.11 respectively. The multiple metal tolerant $P$. aeruginosa HMT 7 significantly influenced the observed parameters and contributed to plant growth under heavy metals stress conditions.

Table 3

The effect of multiple heavy metal tolerant $P$. aeruginosa HMT 7 on growth and biomass of wheat seedling under heavy metal stress conditions $(1,000$ mg $\mathrm{Zn} / \mathrm{kg}, 1 \mathrm{mg} \mathrm{Cd} / \mathrm{Kg}$ and $1 \mathrm{mg} \mathrm{Pb} / \mathrm{Kg}$ amended soil). Data are recorded after 45 days of germination; datais presented as means of 3 replicates \pm SD (standard deviation)

\begin{tabular}{|c|c|c|c|c|c|c|c|c|c|c|c|c|}
\hline Treatment & $\begin{array}{l}\text { Shoot } \\
\text { length } \\
\text { (cm) }\end{array}$ & $\begin{array}{l}\text { Shoot } \\
\text { length } \\
\text { Stress } \\
\text { Tolerance } \\
\text { Index }\end{array}$ & $\begin{array}{l}\text { Root } \\
\text { length } \\
\text { (cm) }\end{array}$ & $\begin{array}{l}\text { Root } \\
\text { length } \\
\text { Stress } \\
\text { Tolerance } \\
\text { Index }\end{array}$ & $\begin{array}{l}\text { Shoot } \\
\text { Fresh } \\
\text { weight } \\
\text { (g) }\end{array}$ & $\begin{array}{l}\text { Shoot } \\
\text { Fresh } \\
\text { weight } \\
\text { Stress } \\
\text { Tolerance } \\
\text { Index }\end{array}$ & $\begin{array}{l}\text { Root } \\
\text { Fresh } \\
\text { weight } \\
\text { (g) }\end{array}$ & $\begin{array}{l}\text { Root } \\
\text { Fresh } \\
\text { weight } \\
\text { Stress } \\
\text { Tolerance } \\
\text { Index }\end{array}$ & $\begin{array}{l}\text { Shoot } \\
\text { Dry } \\
\text { weight } \\
\text { (g) }\end{array}$ & $\begin{array}{l}\text { Shoot } \\
\text { Dry } \\
\text { weight } \\
\text { Stress } \\
\text { Tolerance } \\
\text { Index }\end{array}$ & $\begin{array}{l}\text { Root } \\
\text { Dry } \\
\text { weight } \\
\text { (g) }\end{array}$ & $\begin{array}{l}\text { Root } \\
\text { Dry } \\
\text { weight } \\
\text { Stress } \\
\text { Tolerance } \\
\text { Index }\end{array}$ \\
\hline T0 & $\begin{array}{l}16.11 \\
\pm 1.45\end{array}$ & - & $\begin{array}{l}8.53 \pm \\
0.85\end{array}$ & - & $\begin{array}{l}0.93 \pm \\
0.2\end{array}$ & - & $\begin{array}{l}0.31 \pm \\
0.03\end{array}$ & - & $\begin{array}{l}0.2 \pm \\
0.01\end{array}$ & - & $\begin{array}{l}0.15 \pm \\
0.01\end{array}$ & - \\
\hline TZ1 & $\begin{array}{l}9.12 \pm \\
1.04\end{array}$ & 0.57 & $\begin{array}{l}5.18 \pm \\
0.29\end{array}$ & 0.60 & $\begin{array}{l}0.42 \pm \\
0.10\end{array}$ & 0.45 & $\begin{array}{l}0.11 \pm \\
0.01\end{array}$ & 0.35 & $\begin{array}{l}0.13 \pm \\
0.01\end{array}$ & 0.65 & $\begin{array}{l}0.09 \pm \\
0.01\end{array}$ & 0.60 \\
\hline TZ2 & $\begin{array}{l}20.78 \\
\pm 1.64\end{array}$ & 2.28 & $\begin{array}{l}9.8 \pm \\
0.67\end{array}$ & 1.89 & $\begin{array}{l}1.27 \pm \\
0.32\end{array}$ & 3.02 & $\begin{array}{l}0.43 \pm \\
0.02\end{array}$ & 3.91 & $\begin{array}{l}0.25 \pm \\
0.01\end{array}$ & 1.92 & $\begin{array}{l}0.19 \pm \\
0.01\end{array}$ & 2.11 \\
\hline
\end{tabular}

\section{Discussion}

Occurrence of heavy metals in soil samples is a direct evidence of contamination through ore mining and other anthropogenic activities in nearby area. The rhizospheric soil samples of the present study were found contaminated with a high degree of heavy metals including $\mathrm{Zn}, \mathrm{Cd}$, $\mathrm{Pb}$ and Fe. The excess of heavy metals in the soil samples collected from Zawar region is due to the ore mining activity of the Zawar group. Several reports have confirmed the accumulation of heavy metals in the soil and water resources caused by industrial discharge or effluent of mine tailings $[16,17,18]$. Rhizospheric microorganisms exposed to toxic heavy metals may develop resistance.

The common heavy metal tolerant bacteria as reported in previous studies were found to be member of Enterobacteriaceae, Pseudomonadaceae and Flavobacteriaceae family including Pseudomonas spp., Alcaligenes spp., Enterobacter spp. etc. [19, 20, 21]. The gram-negative bacteria are considered to be more metal tolerant as compared to gram-positive bacteria as the two layers of cell membrane and large amount of lipid is found in gram-negative bacterial cell wall [22]. This lipid binds the excessive heavy metal (zinc, lead) ions enabling them to resist it and grow at higher metal concentration than gram-positive bacteria. This may be possible reason for finding $P$. aeruginosa HMT 7 in the present study which showed fairly high MIC value towards zinc and efficiently tolerated multiple heavy metals used in the study.

It has been reported that metal resistance and antibiotic resistance are correlated [23, 24], therefore $P$. aeruginosa HMT 7 was tested for its antibiotic resistance and susceptible profile. P. aeruginosa HMT 7 showed resistance to six different antibiotics. Due to the increased use of antibiotics in agriculture, microorganisms are developing resistance either by natural mutation or by transfer of resistant genes between themselves. Heavy metals along with antibiotics create a selective pressure that help microorganisms to adapt for better survival in multiple stress conditions [25]. Thus, resistance to both heavy metals and antibiotics make $P$. aeruginosa HMT 7 more ecologically favourable. The strain also harbours plasmid which opens a possibility of plasmid mediated resistance and clustering of genes for better survival.

The possible reasons for the high metal tolerance ability of bacteria surviving in metal-contaminated environments are attributed to some detoxifying mechanisms developed by these strains such as accumulation and adsorption ion exchange on the cell surface, binding and complexation by exopolysaccharides, bioaccumulation and sequestration in cell compartments or heavy metal efflux [26]. Gram negative bacterial mechanisms of resistance to heavy metal ions are sometime encoded in plasmid genes facilitating the transfer of toxic metal resistance from one cell to another [27]. The high tolerance level of $P$. aeruginosa HMT 7 in the present study was due to bioaccumulation of heavy metals which was confirmed by TEM analysis and also might be presence of plasmid containing metal tolerant genes as the isolate found to harbor a plasmid of $23 \mathrm{~Kb}$ size.

There was decrease in all estimated growth characteristics (root and shoot length and dry and wet root and shoot weight) of wheat plantlets in presence of heavy metals in soil. These results are conformity with ealier report [28]. The improved growth of wheat plantlet under heavy metals stress conditions with multiple metal tolerant $P$. aeruginosa HMT7 in the present study was due to the bioaccumulation of heavy metal by the bacterial isolate and the reduced accumulation and uptake of heavy metals in the wheat plantlet. This is in accordance with the findings of the earlier workers [29, 30,31] who reported that the inoculation of metal tolerant rhizobacteria alleviates the metal toxicity and supports plant growth.

\section{Conclusion}

The overall study shows that $P$. aeruginosa HMT 7 has high capacity to tolerate multiple heavy metals. The application of bacterial isolate significantly improved the growth in wheat plantlet under heavy metal stress conditions. Bioaccumulation of heavy metals inside the strain minimized the heavy metal bioavailability in the rhizosphere. The strain also showed resistance to wide range of antibiotics. This is a non-beneficial implication as the presence of metal tolerance mechanisms may contribute to the increase in antibiotic resistance. This strain could help in the bioremediation of heavy metal contaminated 
agricultural field for better growth and yield of the crop.The genetic capacity of the strain could be exploited for the effective remediation of heavy metal polluted sites. The inoculation of $P$. aeruginosa HMT 7 as a biotechnological tool for reducing the heavy metal toxicity will help in understanding various adaptive processes which are poorly understood till date.

\section{Declarations}

\section{Acknowledgement}

The financial assistance in the form of Fast Track Young Scientist Scheme Project from SERB, DST, New Delhi is gratefully acknowledged.

\section{Author contributions}

H.J designed the research and interpreted the data. M.S. performed the experiments.

\section{Conflict of interest}

The authors have no conflicts of interest to declare.

\section{References}

1. Micó C, Recatalá L, Peris M, Sánchez J (2006) Assessing heavy metal sources in agricultural soils of a European Mediterranean area by multivariate analysis. Chemosphere 65:863-872

2. Sheng JJ, Wang XP, Gong P, Tian LD, Yao TD (2012) Heavy metals of the Tibetan top soils level, source, spatial distribution, temporal variation and risk assessment. Environ Sci Pollution Res 19:3362-3370

3. Briffa J, Sinagra E, Blundell R (2020) Heavy metal pollution in the environment and their toxicological effects on humans. Heliyon 6(9):1-26. https://doi.org/10.1016/j.heliyon. 2020.e04691

4. Nkwunonwo UC, Odika PO, Onyia NI (2020) A Review of the Health implications of heavy metals in food chain in Nigeria. Scientific World J 2020:1-11. https://doi.org/10.1155/2020/6594109

5. Sall ML, Diaw AKD, Gningue-Sall D, Efremova Aaron S, Aaron J-J (2020) Toxic heavy metals: impact on the environment and human health, and treatment with conducting organic polymers, a review. Environ Sci Pollution Res. 27:29927-29942. https://doi.org/10.1007/s11356-020-09354-3

6. Srivastava V, Sarkar A, Singh S, Singh P, de Araujo ASF, Singh RP (2017) Agroecological responses of heavy metal pollution with special emphasis on soil health and plant performances. Front Environ Sci 5:1-19. https://doi:10.3389/fenvs.2017.00064

7. Yao H, Xu J, Huang C (2003) Substrate utilization pattern, biomass and activity of microbial communities in a sequence of heavy metal polluted paddy soils. Geoderma115:139-148

8. Kaur H, Garg N (2021) Zinc toxicity in plants: a review. Planta 253(6):129. https://doi.org/10.1007/s00425-021-03642-z

9. Sheoran AS, Sheoran V (2006) Heavy metal removal mechanism of acid mine drainage in wetlands: A critical review. Miner Eng 19:105-116

10. Ozlu E, Kumar S (2018) Response of soil organic carbon, pH, electrical conductivity, and water stable aggregates to long-term annual manure and inorganic fertilizer. Soil Sci Soc Am J 82:1243-1251. https://doi.org/10.2136/sssaj 2018.02.0082

11. Luli GW, Talnagi JW, StrohI WR, Pfster RM (1983) Hexavalent chromium resistant bacteria isolated from river sediments. Appl Environ. Microbiol. 46(4):846-854

12. Weisburg WG, Barns SM, Pelletier DA, Lane DJ (1991) 16S ribosomal amplification for phylogenetic study. J Bacteriol 173:697-703

13. Bauer AW, Kirby WM, Sherris JC, Turck M (1966) Antibiotic susceptibility testing by a standardized single disk method. Am J Clin Pathol 45:493-496

14. Sambrook I, Pritch EF, Maniatis T (1989) A laboratory manual, $2^{\text {nd }}$ ed. Cold Spring Harbor Laboratory Press, Cold Spring Harbor, NY, pp. 6.3

15. Burd GI, Dixon DG, Glick BR (1998) A plant growth-promoting bacterium that decreases nickel toxicity in seedlings. Appl Environ Microbiol 64:3663-3668

16. Yang Q, Li Z, Lu X, Duan Q, Huang L, Bi J (2018) A review of soil heavy metal pollution from industrial and agricultural regions in China: Pollution and risk assessment. Sci Total Environ 642:690-700. https://doi.org/10.1016/j.scitotenv.2018.06.068

17. Mohapatra DP, Kirpalani DM (2017) Process effluents and mine tailings: sources, effects and management and role of nanotechnology. Nanotechnol Environ Eng 2:1-12 https://doi.org/10.1007/s41204-016-0011-6

18. Bhattacharya P, Sracek O, Eldvall B, Asklund R, Barmen G et al (2012) Hydrogeochemical study on the contamination of water resources in a part of Tarkwa mining area, Western Ghana. J Afr Earth Sci 66-67:72-84

19. Pramanik K, Mitra S, Sarkar A, Maiti TK (2018) Alleviation of phytotoxic effects of cadmium on rice seedlings by cadmium resistant PGPR strain Enterobacter aerogenes MCC 3092. J Hazard Mater 5(351):317-329.

20. Kolawole SE, Obueh HO (2015) Evaluation of the minerals, heavy metals and microbial compositions of drinking water from different sources in UtagbaUno, Nigeria. J Health Environ Sci 2:6-10.

21. Mishra N, Gupta G, Jha PN (2012) Assessment of mineral phosphate-solubilizing properties and molecular characterization of zinc-tolerant bacteria. J Basic Microbio 52:549-558.

22. Ferris FG, Beveridge TJ (1986) Site specificity of metallic ion binding in Escherichia coli K-12 lipopolysaccharide. Can J Microbiol 32:52-55.

23. Wani PA, Zaidi A, Khan MS (2009) Chromium reducing and plant growth promoting potential of Mesorhizobium species under chromium stress. Bioremediation J 13: 121-129. 
24. Glibota N, Grande MJ, Galvez A, Ortega E (2020) Genetic determinants for metal tolerance and antimicrobial resistance detected in bacteria isolated from soils of olive tree farms. Antibiotics 9(8):476. https://doi.org/10.3390/antibiotics9080476

25. Zheng Qi, Yue Qi, Zhiwei Le, Furui Han, Fang Li, Hong Yang, Tielin Zhang, Yajie Feng, Rijia Liu, Yuan Sun (2021) The interactions between antibiotic resistance genes and heavy metal pollution under co-selective pressure influenced the bio-enzyme activity. Front Chem 9:691565 https://doi.org/10.3389/fchem.2021.691565

26. Gadd GM (1990) Heavy metal accumulation by bacteria and other microorganisms. Experientia 46:834-840.

27. Silver S (1996) Bacterial resistances to toxic metals-A review. Gene179:9-19.

28. El-Meihy RM, Abou-Aly HE, Youssef AM, Tewfike TA, El-Alkshar EA (2019) Efficiency of heavy metals-tolerant plant growth promoting bacteria for alleviating heavy metals toxicity on sorghum. Environ Experimental Bot 162:295-301. https://doi.org10.1016/j.envexpbot.2019.03.005

29. Rizvi A, Zaidi A, Ameen F, Ahmed B, AlKahtani MDF, Khan MS (2020) Heavy metal induced stress on wheat: phytotoxicity and microbiological management. RSC Advances 10(63):38379 38403. https://doi.org/10.1039/d0ra05610c

30. Pramanik K, Mitra S, Sarkar A, Soren T, Maiti TK (2017) Characterization of cadmium-resistant Klebsiella pneumonia MCC 3091 promoted rice seedling growth by alleviating phytotoxicity of cadmium. Environ Sci Pollution Res 24(31):24419-24437.

31. Han H, Wang Q, He LY, Sheng XF (2018) Increased biomass and reduced rapeseed Cd accumulation of oilseed rape in the presence of Cd-immobilizing and polyamine-producing bacteria. J Hazard Mater 353:280-289.

\section{Figures}

Matches:

Library

RTSBA6 6.10

DCI INIK 6 in

\author{
Sim Index Entry Name \\ 0.403 Pseudomonas-aeruginosa-GC subgroup B \\ ก 750 Dcaudomnnac-apruoinnca-mucoid strains
}

\section{Figure 1}

Fatty acid profile of isolate HMT 7. SIM index reached to 0.752 and strain suggested by the MIDI software was Pseudomonas aeruginosa 


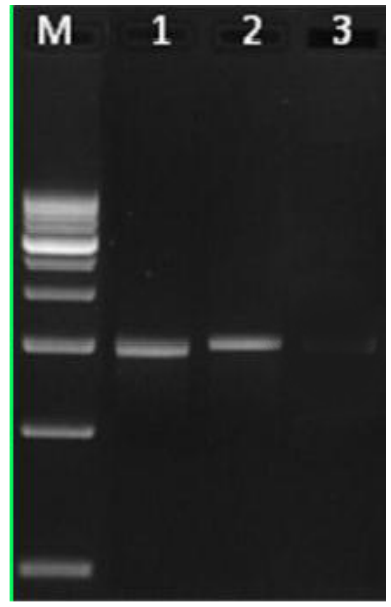

\section{Figure 2}

PCR amplicons of 16S rRNA genes in multiple heavy metal tolerant bacterial isolate. Lane M: StepUpTM 500bp DNA ladder, Lane 1: Isolate HMT 7, Lane 2: positive control (P. aeruginosa, MTCC10311) Lane 3: negative control

\section{Figure 3}

TEM analysis of the $P$. aeruginosa HMT 7 cells grown for $24 \mathrm{~h}$ in nutrient broth A) without and B) zinc sulphate heptahydrate (30 mg/ml) and $100 \mu \mathrm{g} / \mathrm{ml}$ each of cadmium chloride and lead nitrate showing electron dense grains distributed within the cell (Bar=500 $\mathrm{nm}$ )

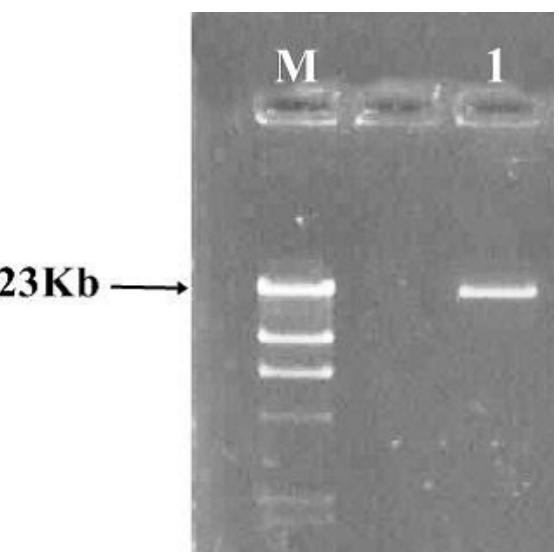

\section{Figure 4}

Plasmid DNA profile of P. aeruginosa HMT 7, Lane M- Lambda Hind III digest DNA marker and Lane 1- P. aeruginosa HMT 7 